\title{
MESSAGES FOR HUMANITY IN "BULA MALINO" (QUIET MOON) (A POEM BY KAIMUDDIN IDRUS MUHAMMADAL- BUTHUNI IBNU BADARUDDIN)
}

\author{
Kamaluddin ${ }^{1}$, Zainal Rafli ${ }^{2}$ \\ ${ }^{1}$ Halu Oleo University Kendari, Indonesia \\ ${ }^{2}$ Universitas Negeri Jakarta, Indonesia \\ ${ }^{1}$ kamaluddin_zamani@yahoo.com, ${ }^{2}$ zainal.rafli@unj.ac.id
}

\begin{abstract}
"Bula Malino" (Quiet Moon) is a literary work found in Buton society and packaged in the form of poem. The manuscript is written in Wolio Language (Butonese main native language) using an Arabic-Wolio script modification, commonly called "buri Wolio" (Wolio writing). This article is yielded to report findings of a qualitative study which analyzes the humanity messages revealed in the poem using a content analysis and structuralism genetic approach. This approach follows some gradual procedures such as examining intrinsic elements of poem, reviewing social life of author, and giving a reflection to history and social background of Buton society. The findings show that the poem reveals messages and values for humanity in terms of sobriety or calm mind/heart and soul clarity for being prepared for death. The poem also contains advice addressed to readers. It was noted that the author of the poem was born in the late $18^{\text {th }}$ century $A D$. At the age of 40 , he was inaugurated the $29^{\text {th }}$ sultan of Buton. At this century, Buton social condition was more than enthusiastic in learning science. This was marked by the establishment of a school named "Zaawiah".
\end{abstract}

Keywords: humanity; structuralism.

In general, literature is an expression of human's experience and problems they undergo in life which is packed with the author's subjectively personal viewpoints. In Sanskrit, it is called "Shastras" which means "text containing instruction" or "guidance", as meant from its root "śās-' meaning "instruction" or "teaching". The word literature itself is derived from the Latin "Littera" (alphabeth), which is the smallest element of a text. The word "text" is associated with the word "textiles" which can be understood as "cloth"; that is, similarly a single thread forming fabric, thus a word and a sentence can form a coherent text (Christopher, 2001).

Literature is presented into written and oral form. Here, literature is not merely seen as something related to written product but as language used as a vehicle to express certain thoughts or ideas. Literature is also considered as cultural and historical phenomenon. It is human intention to always express that underlies certain literary work, thus, literary expression can be assumed to be older than the creator himself.

It is noted that literature is a social institution that uses language as a medium to describe the life of a social reality (Damono, 1978). It can be assumed that a literary work is part of the culture; its existence within community is a reflection of social and cultural phenomenon. The reflection and the influence are reciprocal, suggesting that literature can influence and be influenced by society. It can be said that the literary work is a picture of life. Therefore, the process of creating literary works 
mostly portrays a continuity between the value of social reality and ideal value of the author.

A literary work "Bula Malino" (quiet moon) is one of the Wolio language literary found in Buton society and packaged in the form of poem. This text is written using a modified Arabic script, commonly called "buri Wolio" (Wolio script). The poem was written by Muhammad Ibn Badaruddin Kaimuddin K. Al-Buthuni. He is a writer and also the $29^{\text {th }}$ Sultan of Buton Sultanate, who ruled from 1824 to 1851 (La Niampe, 2009).

During his reign, education in Buton/Wolio witnessed a remarkable era; the first reported school named "Zaawiah" was established. It was so lively and enthusiastic of the delivery of education at that time that teachers or scholars from outside were imported exclusively by the kingdom to improve the quality of public education. Many students from outside also came to learn and explore science in Buton (Said, 1999).

The selection of the literary work "Bula Malino" to be analyzed in this paper has been for the fact that the poem has been transliterated from Wolio script "Buri Wolio" into Latin script to facilitate the writer and readers to read the manuscript. In addition, humanity messages contained in the poem is still considerably relevant to be studied and applied in public life today.

Messages for humanity or humanity aspect is stated in the Preamble of 1945 Constitution of the Republic of Indonesia which states that colonization over the world should be abolished because it does not comply with humanism and justice. This suggests that all the basic rights of human life must be protected and upheld by all parties. Humanitarian issue is, in fact, a universal problem as noted in the declaration of universal conventions (UN Charter) on human rights dated December 10, 1948 (see also Guidelines of Human Rights Education). The poem "Bula Malino" written in about 1824-1859 has talked a lot about the messages of humanity, so that the selection to this literary work in analysis is justified. This study attempts to answer the following questions: (1) What are the humanity messages contained in the poem "Bula Malino"?; (2) How are the humanity messages portrayed in the poem 'Bula Malino'?; (3) How is the life and background of the author?; (4) What is the existence of society during the author's life?

The results of this study is of importance that it provides information about how the humanity messages contained in the poem "Bula Malino", how the messages are portrayed, the life and background of the author, and the existence of society during the poem's writing. Finally, the results of this study could be used as the basis for further researchers interested in doing a follow-up study.

\section{Approach in Research Literature}

In a literature study approach, it is plausibly to operate a number of theories and methods. Approach is the recognition of the scientific nature of the object of science itself. Approach is the first step in realizing the objectives of the research. According to Abrams (1979) model of literary approach is divided into four major groups, namely; expressive, pragmatic, mimetic, and objective.

First, expressive approach gives attention to how the work is created and what forms are happening in the literary works produced. The study area of this approach is author-self, thoughts and feelings, and the results of his work. This approach utilize more on secondary data, those which have been taken from the author's 
activities by investigating such characteristics of individualism, nationalism, communism, feminism, and all the other works either of individual literary works and literary works within the framework of periodization.

This expressive approach puts literature as an outpouring of speech and thoughts and author's feelings. Here, the author himself becomes the subject that produces a combination of perceptions, thoughts, and feelings. Practice analysis of this approach leads to a search of authenticity of author's personal vision which is called worldview based on the genetic structuralism. Often this approach seeks facts about the special character and experiences of authors who either consciously or not has portrayed himself in his work. Thus, conceptually and methodologically, it is realized that the expressive approach puts literature as: (i) the form of expression of the author, (ii) the product of author's imagination on his perceptions, thoughts and feelings, and (iii) the product of author's worldview.

Secondly, mimetic approach begins with the realization that literature can not represent the reality but only as imitation of reality. The reality here is used in the broadest sense, i.e. everything that is both outside literature and referred by the literature, such as objects that can be seen and touched, forms of society, feelings, thoughts, and so forth. Through this view, the artwork is hierarchically under a reality.

According to Baxter (http://sites.google.com/site/johnbaxterparis/20 June / 2012) mimetic is an ongoing dynamic relationship between a fine art work and the universe as factual and plausible moral. Mimesis is often translated as "artificial". In terminology, mimetic art signifies a presentation art or a resemblance, but the emphasis is different. Artificial implies something static, a copy, a final product; while mimesis involves something dynamic, a process, an active relationship with a fact of life. Furthermore Baxter argued that, the best method for mimetic is to strengthen and deepen understanding of moral, and to investigate and interpret the universe which is really accepted. In fact, the reality is sometimes described differently because it does not fit with the overall view of reality. Therefore, the fact can not be presented in the work with ideal coverage.

The above explanation suggests that conceptually and methodologically mimetic approach puts literature as: (i) the work of imitation (artificial) of reality which is realized dynamically, (ii) a representation of universe reality which is translated in fiction, (iii) the work or dynamic product that its reality does not possible to present coverage ideally, and (iv) work or imagination with the highest awareness of reality.

Third, pragmatic approach or so-called reception theory gives particular attention to the role of the reader. In this approach, the interpretation of the reader is the most decisive. This approach gives attention to shifts and new functions of readers with various competence to consider literary works implications on readers. In regard to indicators of literature and the readers, problems that can be solved through this approach refer to various public responses or acceptance of a particular reader on a certain literary work, both in terms of agreeing or not agreeing.From the above explanation, it can be concluded that a text can only be present when it is read and needs to be tested through readers' responses. Description of the text is nothing more than the experience of the reader.

Fourth, objective approach/structural approach focuses solely on the elements, interrelationships, and totality. This approach leads to the intrinsic analysis by ignoring even rejecting any extrinsic elements, such as historis aspect, sociological, 
political, and other socio-cultural elements, including a biography. Therefore, the objective approach is also called autonomous analysis. Understanding the literary works is focused on the analysis of the elements by considering the relationship among elements on the one hand and the relationship between the elements and the totality in the other hand. The basic concept of this approach suggests that literary work is a structure consisting of various elements forming a certain structure. Among the elements forming the literary work, there exists a coherence. Each element has no meaning in itself, but its meaning is determined by the relationship with the other elements involved in a situation. The meaning of each element of the literary work can only be completely comprehended on the basis of the placing and function of the elements in the entire literary.

Methodologically, this approach aims to see literature as a system and the value given to the system is highly dependent on the value of the components involved in it. The analysis of literary works through this approach depends on the type of the literary works. For example, analyzing a poem needs a different approach from a prose.

\section{Humanism}

Etymologically, the term humanism is derived from the Latin word 'humus' meaning soil or earth. Then came the word 'homo' which means the man or earth creature. Both words form a new word meaning 'humanus' meaning grounding and humane. Davies (1997) associate the word with the Latin word 'humilis' which means simplicity and humility. The term humanism, in fact, has a different meaning; however, humanism can be basically associated with the human family struggling to understand and interpret the existence of himself and his relationship with human values (Lamont, 1997).

Humanism in its broadest sense is the whole concept of man as the center of existence. Humanism is a movement to uphold human values, which constitute the main purpose of religion. Shari'ati (1992) explains that the internal dimensions of the human can be described based on the principles and humanitarian values that also describe the human characteristics. These characteristics include: the nature of independence, the ability to intend, the ability to be aware and thinking, the ability to be civilized, the ability to give moral consideration, and always strive to realize dreams. This study describes values humanism values contained in the poem of "Bula Malino".

Developed from structural approach model, genetic structuralism analyzes the structure by giving attention to the origin of the work. This approach gives attention to the intrinsic and extrinsic elements. It follows the following procedures by examining: (i) the elements of literature, (ii) the relationship of literature to the totality of literary works, (iii) the background of the author, and (iv) the relationship of literature in society. The object of the study was to obtain an overall picture and deep understanding of messages for humanity in "Bula Malino" (Quiet Moon) a poem by Kaimuddin Idrus Muhammadal-Buthuni Ibnu Badaruddin. 


\section{METHOD}

This study is a qualitative study using content analysis to analyze the meaning contained in the poem "Bula Malino" by applying genetic structuralism approach. This approach begins by reviewing the intrinsic elements of the poem either partially or in whole. Secondly, it examines the background of the social life of the author, and thirdly, it attempts to reflect the history and social background which supports the condition during the creation of the poem by the author (Jabrohim, 2012).

The steps are performed as follows. Firstly, the poem "Bula Malino" structure is studied to show the connection among its parts/elements in order to form a holistic and comprehensive coherence. Secondly, that element is associated with the sociocultural and historical conditions during the creation of the poem which then linked with the author's viewpoints and world. For drawing conclusions, the specific premises are assimilated with each other to achieve a general premise.

Data and data sources are manuscript of "Bula Malino", a literary work in "Wolio" language and is packaged in the form of poem. The text is written using a modified Arabic script, so-called "buri Wolio" (Wolio writing). The poem was written by Mohammed K. Kaimuddin Ibn Al-Buthuni Badaruddin in 19th century. The manuscript has been transliterated from "buri Wolio" (Wolio writing) into Latin writing (letter).

\section{RESULTS}

In general literature of Quiet Moon written by Muhamad Idrus Kaimuddin Ibnu Badaruddin Al-Buthuni contains messages and human values. Hence he asked the Lord to always given readiness, strength of faith and can pledge shahadah firmly, as scited below.

"Bismillahi kaasi Karoku si / In the name of God, bless of me

Alhamdu padaka kumatemo / Praise, I will soon die

Kajanjina mo yoputa makaana / It is the providence of Almighty God

Yapekamate bari-bariya batuya / Off all servants

Yinda samia batuya bemolagina / No one also eternal servant

Sakabumbuya posa Matemo / All will die

Somo yopu yalagi samangengea / Only God is eternal

Sakiyayiya Yinda kokapada / Forever never-ending

Ee Waopu dawuaku iymani / O Lord, give me faith

Wakutuna ku boli badaku siy/ At the time of leaving the body

Te Sahada ikiraru momatangka / With an unwavering pledge creed

Te tasidiki iymani mototapu / And the affirmation of faith that remains. "

\section{(1) Messages and humanitarian advice of poem}

There are five messages contained in the poem as bellow descriptions.

(i) Do not be drunk with the world pleasure

He invites to always introspective, do not be complacent or drunk with pleasure. Priority must think and do is a good deed to relatives and friends. However, if the 
death pick us up, we are divoeced with everything, such as the following are destined.

"Ee Karoku bega-begana yumalanga / O myself, do not be drunk

Yinda fikiri kampodona umurumu / Don't you think the rest of the your age?

Matemo yitu tayomo papogaako / death that would divorce

Te malingu Sabara manga anamu / with all your children

Temo dukaSabara musirahamu / and also all acquaintances

Wititinai atawa mosaganana / family or others ".

(ii) Teaching and love yourself; Do not follow the passions

The authors suggest to love yourself by not following the will of lust, except the "radiyah lust" and "Mardiyah lust".

"Ee Karoku yada yadari karomu / O myself, teach-yourself

Nafsuumu bega-begana uyosea / Don't follow your

Tabeyanamo nafusu rayudiyah / except for “radiyah” lust

Nafusu isarongi maradiyah / lust named Mardiyah

Mo sarewu guru bemoyadariko / though a thousand teachers who teach

Yinda mo Lawana yuda-yudari karomu / unequaled teach yourself

Motuyapa kasina miya yitu / Despite what people love it

Yinda beakawa kasina yikaromu / unequaled love yourself ".

(iii) Do not brag and slandering others

On the Day of Resurrection those who love slander would be punished. He described his words as cited below.

"Ee Karoku, boli mangabuya-buya / O myself don’t brag

Temo duka boli manga humbu humbu/and also don't slander

Kadakina tabuya-buya rangata / ugliness lied others (people)

Hari kiyama nayile beyu marimbi / On the Day After, later you ll be punished

Kadakina tahumbu miya rangamu / ugliness malign neighbor

Yokadakina yula meya yingko / ugliness that you take

Yokalapena posaleya yinciya / the rightness all he took

Hari kiyama delamu beya totunu / On the Day of Judgment your tongue will be burned ".

(iv) Do not put the power and nobility

The author stated that the need to take precedence conscience is always pure and clean. With a clear conscience and clean will be eternal to the day later.

"Ee Karoku fikiriya mpu-mpu / O myself think strongly

Kakawasa tangkanamo iyi duniya / power only exists in the world

Yoka lalaki tangkanamo yiwesi / nobility only here

Te malingu kabelokana duniya / and all garnish of the world

Ta kawaka naile muri-murina / until the day after

Yama pupumo Bariya bari-situ / drop it all

Tangkanamo totona yinca mangkilo / the only a clear conscience

Bemolagina naile muri-murina / eternal (lasting for ever) 
(v) Do not like to lie

Doing the goodness will receive the Lord's protection at teh day after. He described his words as cited below.

"Ee Karoku boli upake pewilu / O myself do not wear lie Aboasaka Saro inda motindana / said something are not clear Barangkana upakea incia yitu / that has been put on such a Amadakimo i lipu rua nguna / perished in the two worlds Neu kabonga boli upalalo sara / when tinkering do not beyond the limit Tontomakea laengana morangoa / note who hear it Neu kabonga podo shabu-sabutuna / when joking, limit it Upekalape incana miarangamu / repair neighbor's heart Tabeanamo te Antona banuamu / except with your household Inda pokia nea tolabi saide / it's ok if too little Upatotapu rouna pomananea / set to face each other Sarona upekatangka pomusiraha / its name strengthen friendship Ijitihadi umbore i Duniya / beware inhibit this world Nunua mpu saro imalapeaka / Investigate the name of goodness Sio-siomo Opu apaliharaku / May Lord kept me I hura-hura naile muri-murina / In the commotion in the day after ".

\section{(2) The elements contained in the poem}

(i) The theme of the poem

Theme in the literature generally describes nothing eternal in this world except God Almighty. In his work he urged to always clear the mind and heart that he symbolized as "Quiet Moon". However, the Quiet Moon is actually the clarity and peace of mind as a provision in the provision of life and social skills in a day after, as it is scited below.

"Ee Karoku yincamu pekangkiloa / O myself, purify yourselves.

Nganga randamu boli yumanga pipisi / Your Intentions don't under estimate others. Temo duka boli yumanga pisaki / And also do not look lightly

Kakawasa tangkanamo iyi Duniya / power only exists in the world Yokalaki tangkanamo yiwesi / nobility only here

Te malingu kabelokana Duniya / and all garnish world

Ta kawaka naile muri-murina / until the day later

Yama pupumo Bariya bari-situ / drop it all

Tangkanamo totona yinca mangkilo / only a clear conscience

Bemolagina naile muri-murina / eternal in the day after".

(ii) Rima (repetition of words)

The repetition of the word "Ee Karoku / O myself" repeated as many as eighteen times. Eighteenth word is described in the following sentences.

"Ee Karoku, bega-bega yumalango / O myself, do not be drunk

Ee Karoku, yada-yadari karomu / O myself, teach yourself

Ee Karoku, menturu sambaheya / O myself, often do pray

Ee Karoku, boli yumanga buya-buya / O myself, do not like brag

Ee Karoku, yincamu pekangkiloya / O myself, purify yourselves 
Ee Karoku, fikiriya mpu-mpu / O myself, think really

Ee Karoku, togasaka mpu-mpu / O myself, berpasrah lah betul- right

Ee Karoku, tawakala mpu-mpu / O myself, acceptant really

Ee Karoku, bega-bega mengkoni / O myself, do not say more word

Ee Karoku, boli upake pewilu / O myself, do not lie

Ee Karoku, paihilasia yincamu / O myself, purrify your heart

Ee Karoku, ihlasi atopene / O myself, put the heart in His way

Ee Karoku, pekatangka pengkenimu / O myself, reinforce your hand

Ee Karoku, Ombu on aumbamo / O myself, doom already come

Ee Karoku, keniakamea mpu / O myself, cling right

Ee Karoku, rangoa tula-Tulana / O myself listen to his story

Ee Karoku, fikiria mpu-mpu / O myself, think really

Karoku ee, mate padaaka aumbamo / O myself, death later will come "

(iii) Style language used in the poem

The style of language in the poem using the language simile style. Many express words "like", as cited below .

"Ee Karoku togasaka mpu-mpu / O myself, real acceptant

Yokadakina finana Duniya / ugliness of world defamation

Pamana bose padaka yuhelamo / like a sail soon leave

Yinda beyu lagi lipu podagamu / not be lucky in your trade the country "

\section{(3) The background of the writer}

Muhammad Idrus Kaimuddin Ibnu Badaruddin Al-Buthuni born in the late 18th century AD at age 40, he was inducted into the sultan of Buton to 29. He ruled in 1824 up to $1851 \mathrm{M}$

\section{(4) The social condition}

The social condition of the people of Buton in the late 18th century. Buton social condition in this era is very enthusiastic in learning science. It is characterized by the establishment of school named "Zaawiah".

\section{DISCUSIONS}

In general literature of Quiet Moon contains messages and human values. Writer started writing to say that one day he would face death. He stressed that by remembering our dead faith will grow and will always be aware of ourselves to always do good and humble. He also invites readers to always cleanse and purify ourselves and surrender to the will of the Creator. This is the will of God for all His creatures. None of the eternal servant of God in the world.

Quiet Moon is a symbol of peace of mind, clarity of heart to prepare for death. Writer invites readers to constantly clean themselves from the intentions, the words to the deeds. He invites to always introspective, do not be complacent or drunk with pleasure.

He stated that the need to take precedence conscience is always pure and clean. With a clear conscience and clean will be eternal to the day after. For that, he invited 
not to brag and slander. In order to not always behave based on power and nobility. He also asked the Lord to always given readiness, strength of faith and can pledge shahadah firmly.

\section{(a) Messages and humanitarian advice of poem}

The Poem contains several messages and humanitarian advice addressed to the reader but in conveyening the meaning, author begins with the word "Karoku" (myself). The use of the word "Karoku" shows humility of the writer even though he was also true at the time of writing the poem served as the Sultan of Buton. He holds fast to the principle that before advising others first advising yourself.

The Poem of Quiet Moon is a symbol of peace of mind, clarity of heart to prepare for death. author invites readers to constantly clean themselves that at the start of the intention, the words to the deeds. He suggests to always introspective ourselves, do the best to relatives and friends. Even if a thousand people who teach us to be better teach yourself.

He also says, if people do boasting and slander, all the goodness of people who brag and slander will be taken of people who lied and slandered and maligned otherwise all the ugliness that captured people who slander. Power and nobility only trinkets's greatness will soon disapear along with the turnaround of time.

Further more, the poem states that do or avoid false words that say something is not clear. When we lie then perished two things, they are the world and the hereafter. He also advised when making joke do not exceed the limit, except with your family, the whole house. The most basic is taken carefully inhibit this world.

\section{(b) The elements contained in the poem}

Theme in the literature describes nothing eternal in this world except God Almighty. Here the author clearly appealed to constantly purify themselves and do not patronize or underestimated others. Power and nobility (rank and position) simply garnish the world. And when the time comes (death) so all will be disapeared except a clear conscience that will be eternal and immortal. Heart or pure conscience will be equipped us in the world and the here after later.

In other hand, repetition of the word "Ee Karoku / O myself" repeated as many as eighteen times. The author began writing the phrase "Bismillahi kasi si Karoku / In the name of God, it is a pitty of myself." Writing the sentence above shows that surrender to the will of God. Then the repetition of the word "Ee Karoku / O myself" show humility of the author and this also indicates that the style of language is simile style.

\section{(c) The background of the writer}

Muhammad Idrus Kaimuddin Ibnu Badaruddin Al-Buthuni was inducted into the sultan of Buton to 29, at age 40. He ruled in 1824 up to $1851 \mathrm{M}$ (La Niampe, 2009). . When he was young, he receive Islamic education from his own grandfather named La Jampi. La Jampi was a Sultan of Buton with the title of Sultan Sultan Qa'im alDin Tua (1763-1788).

As followers of the Sufi Khalwatiyah Sammaniyah influenced by one of his teachers Syek Muhammad bin Syais Sumbul al-Maliki, Muhammad Idrus not only concerned with remembrance but also retreat (aloof from the crowd). It seems seclusion practiced Muhammad Idrus. is like seclusion Prophet Muhammad in the 
Cave of Hira before the revelation down (Said, 1999). He divides seclusion into three levels, namely: salik seclusion, seclusion wise, and seclusion muthlaq.

The first is the seclusion salik (students) who studied tasauf and lead the congregation. Seclusion wise is done with care, although sports or body in the middle of the crowd. Medium seclusion mutlaq can only be done by "Gaus" is the highest peak levels of Sufi (Interview Ma Sabri, June 2014).

Some writings and other works of Muhammad Idrus is as follows: 1. Jauhara Manikam; 2. Mu'nisah al Qulub fi Dzikr wa-Musyahadah; 3. Diya al-Anwar fi Tashfiyah al-akdar; 4. Kasif al-hijab fi Muraqabah al-Wahbab.

In other writings, Muhammad Idrus. also argued “maqam-maqam” like; repentance, tawadlu, patient, willing, and ascetic. This shows that Muhammad Idrus also influenced by figures of Sunni, while thinking about Wujudiyyah, existence influenced to follow this line of thought.

However, by figures of philosophical. This is evident when he received Wujudiyyah existence he made the concept of the dignity of seven as a teaching Wujudiyyah as a concept in the legislation governing the empire in Buton. Thought tasauf in Buton in the 19th century seems Muhammad Idrus as a sultan who had a very strong idea about the relationship between tasauf with Shari'ah. As in his statement "the highest favor was upon seeing God in Musyahadah". However, he added that it will never be reached before doing the Lord commands like; prayer, fasting, and alms and leave act forbidden (Interview, Ma Sabri, June 2014).

\section{(4) The social condition}

Buton social condition in this era is very enthusiastic in learning science. It is characterized by the establishment of school named "Zaawiah". It is so lively and enthusiastic in the delivery of education at that time that the teacher or the scholars from outside Buton were imported exclusively by the kingdom to improve the quality of public education. In addition, many students from surrounding places came to learn and explore the science in Buton (Said, 1999).

What's interesting about this school is that the students have the freedom to choose the subjects they enjoy and being matured in their daily practice. In addition to religious lesson, some other lessons included economics (business administration), government, law, literature, and military / defense. These lessons were engaged in the curriculum when they have mastered the science of religion (Tassawuf). Therefore, all the tasks and any obligations they entailed in serving the community, attitudes, and their perspectives on something must be based on the guidance and universal value as the Islamic religion. (Kamaluddin, 2012).

In line with that, the places for worshiping were developed extensively. Several mosques were built at that time and until now some were still standing strong such as the Great Mosque and Masjid Sultan Baadia. Mosque Baadia was not only used for worship but also as a place to gain knowledge and deepen the religious sciences. It is estimated that the building of the mosque, which was still standing strong was built in 1825 .

At the same time, several religious schools (Zaawiah) were established simultaneously all over the kingdom. In the country, the Islamic teachers taught or spread education and science which were pioneered by the palace officials as well as ministers and their assistances. The school activities received much support and were welcomed by local community leaders (Flamin, 2002). To establish solid 
educational foundation, Islamis religion had an enormous and important influence to Butonese society. Thus, the first lesson to learn and to teach was Islamic religion".

Implications of the education program launched at that time was as follows. (i) Community palace obliged to use Arabic as a lingua franca.

(ii) the Sultan ordered that every Friday the preacher read Arabic sermon in the mosques. Since then Arabic sermons wich was written by scholars of Buton called "Hutuba Kalulungi" a special sermon. (Flamin, 2002).

(iii) Criteria for a leader is determined as follows: (a) amembali means powerful, strong, power, believed, and obeyed by the public, (b) atomaeka means having authority, (c) aumane means brave (d) akoadhati means based on customary in running the government, (e) atomaasiaka means respected leader, (f) atobungkale means open leadership, (g) atoperangoi means obeyed his order and be heard by the people, and (h) akosobara means he is not emotion but must be patient (Zuhdi et al., 1996).

(iv) In the field of law, the role of "Siolimbona (a sort of parliament, 9 people as representative from 9 region) was confirmed as follows: (a) determine the candidates ofsultan, officers, and employees within the sultanate (b) select and appoint the sultan, (c) terminate or dismiss the sultan and court officials in violation of the provisions of rules, and (d) know all the words of the sultan talks with other royal officials (interview; Maa Sabri, June, 2014).

In that period also a scholar of Buton was sent by the emperor to learn to Egypt. The religious figure named H.Abdul Ganiu known by Buton society as "Kenepulu Bula" (Kamaluddin, 2008). He is also as a writer with some of his works such as: Ajonga Inda Malusa Clothes that never fade, "Kalipopo Mainawa Bright Star, Padhomana Alimu (Guidelines of Alim People), and Kaina-inawuna Arifu (Garden of wise Persons).

\section{CONCLUSION}

The poem "Bula Malino" or quite moon is generally regarded a symbol of sobriety or calm mind/heart and clarity of soul for being prepared for death. Specifically, it is found that the poem contains several messages and human values. The messages can be grouped in five categories as follows. Firstly, the message is about not to be satisfied with pleasure the world; here, the author asks the readers to continually clean themselves from bad intentions, words and deeds. He also asks readers to always be introspective and not to be complacent or drunk with pleasure. The second message refers to need for learning and appreciating one's self since selfrespecting also means valuing others. By this, he intends the readers not to follow bad passions. Thirdly, his message is that one should not boast and slander other people with the belief that boasting and slandering others may take away one's good deed to those boasted and slandered and even, take in their badness. Fourth, his message is that one should not put on his power and nobility since it is only the greatness of the world which will soon disappear in time. He, thus, advised that we should take precedence a pure and clear conscience for it will be eternal until the dayafter. In his fifth message, the author advises to avoid false words that is to say something unclear or untruthful. Lying would destroy someone's life both in the 
world and in the hereafter. By this, he suggests that one should not exceed his limit, be careful, and do good deeds.

The theme of the poem generally describes about nothing being eternal in this world but God as the creator of the universe. The style of language in the poem "Bula Malino" uses a simile as mostly found in the 'Bula Malino' poem such expression as "like".

The author, Muhammad Idrus Kaimuddin, is estimated to be born in the late of 18 th century AD. At the age of 40 , he was inaugurated the $29^{\text {th }}$ sultan of Buton. He ruled from 1824 up to 1851. In his young age, he received Islamic education from his own grandfather named La Jampi, once a sultan with the title of Sultan Qa'im alDin Old (1763-1788). He also received a further lesson from another teacher named Syek Muhammad ibn Syais Sumbul Al-Maliki. As a sultan, the author also has a very strong ideas about the relationship between Tasawuf and Shari'ah. He maintained that one will never reach the highest level in Tasawuf unless practicing such God commands as; praying, fasting, giving alms and leaving all God's forbidden acts.

Buton social condition in 18th century's has witnessed a very enthusiastic phenomenon in learning science. It is characterized by the establishment of a school named "Zaawiah". From this Islamic school, intellectual generation of Buton was born at that time.

\section{REFERENCES}

Abrams, M.H. (1979). The Miror and the Lamp: Romantic Theory and the Critical Tradition, New York: Harcourt Brace \& World Inc.

Baxter, John (http://sites.google.com/site/johnbaxterparis/20 juni/2012)

Damono, Supardi Joko. (1978). Sosiologi Sastra Sebuah Pengantar Ringkas. Jakarta: Pusat Pembinaan dan Pengembangan Bahasa Departemen Pendidikan dan kebudayaan

Davies, Tony. (1997). Humanism. London: Routledge.

Flamin, Sarmin. (2002). Pelaksanaan Syariat Islam pada Masa Pemerintahan Sultan Muhammad Idrus Kaimuddin. Skripsi.Kendari: Unhalu.

Jabrohim. (2012). Teori Penelitian Sastra. Yokyakarta: Pustaka Pelajar.

Kamaluddin. (2012). “Buton dalam Dimensi Pendidikan” , Menyibak Kabut di Keraton Buton. Bau-Bau: Respect Pemkot Bau-Bau.

Lamont, Corliss. (1997). The Philosophy of Humanism, New York: Humanist Press.

La Niampe dan Laode Syukur. (2009). Silsilah bangsawan Buton (Pengantar dan Suntungan Teks) Kendari: Penerbit FKIP Unhalu. 
New, Christopher. (2001). Philosophy of Literature An Introduction. London and New York: This edition published in the Taylor \&Francis e-Library.

Pedoman Pendidikan Hak Asasi Manusia. (1999). (Terjemahan: W.P.Napitupulu). Jakarta: Komnas Indonesia Untuk UNISCO.

Said. (1999). Perjumpaan Islam dan Budaya-Budaya Buton (Spiritualitas, Oralitas, dan Etos Kerja). Kendari: Yayasan Wolio Molagi.

Syari'ati, Ali. (1992). Humanisme antara Islam dan Mazhab Barat (I Insan Al Islam wa Madaris Al Gharb) terjemahan Afif, Muhammad, Jakarta: Pustaka Hidayah.

Zuhdi, Susanto. (1996). Kerajaan Tradisional Sulawesi Tengggara (Kesutanan Buton) Jakarta: Depdikbud. 